\title{
Prospects of insects as food and feed
}

\author{
Arnold van Huis
}

Received: 25 March 2020 / Accepted: 30 March 2020 / Published online: 17 April 2020

(C) The Author(s) 2020

\begin{abstract}
In the last 10 years, the interest to use insects as food and feed has increased exponentially. In tropical zones, insects are a common food item as they are more readily available as food in nature than in other climate zones. However, if we want to promote insects as food and feed, harvesting from nature is not an option and the farming of these animals is required. This can be done in environmentally controlled facilities. Insects are not only nutritionally excellent food; they may also have health benefits. When using organic side streams as substrate, chemical and biological contaminants need to be considered. People in western countries are not used to eating insects, and therefore, strategies to "convince" consumers of their hygienic safety, environmental sustainability, and tastiness are necessary. The insect sector is maturing fast, but still faces many challenges, which can only be met when all stakeholders cooperate closely.
\end{abstract}

Keywords Edible insects · Insects as food and feed . Circular economy $\cdot$ Nutrition and health $\cdot$ Industrial production $\cdot$ Food safety and legislation $\cdot$ Consumer attitudes

\footnotetext{
A. van Huis $(\bowtie)$

Department of Entomology, Wageningen University \& Research, PO Box 16, 6700 AA Wageningen, The Netherlands e-mail: Arnold.vanhuis@wur.nl
}

\section{Introduction}

The consumption of insects by early humans has often been underestimated in comparison to food plants and wild meat (McGrew 2014). Therefore, Lesnik (2017) considered it a western bias that insects have been considered a fall-back food resource, being used only in marginal environments. This notion of insects being a backward and a primitive food habit was contested by DeFoliart (1999). However, it may be understandable why insects in the western world were not eaten, while in tropical zones it was a common food habit. In the tropics, insects are bigger and available throughout the year. The harvesting is also easier, as they are abundant and often they occur aggregated (Van Huis 2018). However, recently it is being realized that insects are not only a nutritious food source but also that they can be reared more sustainably than the common livestock species. Besides, they are a safe protein source which can be used by humans, production animals, fish, and pets. Many efforts are now underway to farm several insect species in large automated facilities.

\section{Which insect species are eaten?}

Jongema (2017) listed more than 2000 edible arthropod species. They belong to the following groups: Coleoptera (beetles, often the larvae) (31\%), Lepidoptera (caterpillars) (17\%), Hymenoptera (wasps, bees, and ants) (15\%), Orthoptera (crickets, grasshoppers, and locusts) (14\%), Hemiptera (true bugs) (11\%), Isoptera 
(termites) (3\%), Odonata (dragonflies), Diptera (flies), and others (9\%). Some of those are eaten throughout the tropics, such as termites and the larvae of palm weevils (Rynchophorous spp.). In central Africa, several caterpillar species are eaten, and in southern Africa the mopane caterpillar, Imbrasia belina, is a common seasonal food item (Photo 1). In the Sahelian region of Africa, many grasshopper species are used as food. In Southeast Asia many insect species are eaten, but to mention just two popular ones: the giant water bug, Lethocerus indicus, and the weaver ant, Oecophylla smaragdina (Photo 2). In Australia, the witchetty grub, either a caterpillar of a beetle larvae, is well-known food of the aboriginals. In Mexico, chapulines, grasshoppers of the genus Sphenarium, a pest of agricultural crops, are popular food, while in Columbia the immature queens of the ant Atta laevigata have been eaten for hundreds of years. The habits of insect eating, also called entomophagy, from people from all over the world have been extensively documented by Bergier (1941), Bodenheimer (1951), and DeFoliart (2002).

\section{Why the recent interest of the western world?}

The increased interest in the developed world for insects either as food or feed, was prompted by the publication of the report Edible insects: future prospects for food and feed security of the Food and Agricultural Organization (FAO) of the United Nations (Van Huis et al. 2013). This report showed that edible insects are a viable and sustainable food option for the future. Dietary change is considered a worldwide necessity as current food systems are a major driver of climate change, changes in land use, depletion of freshwater resources, and pollution of aquatic and terrestrial ecosystems (Springmann et al. 2018). Worldwide, people are

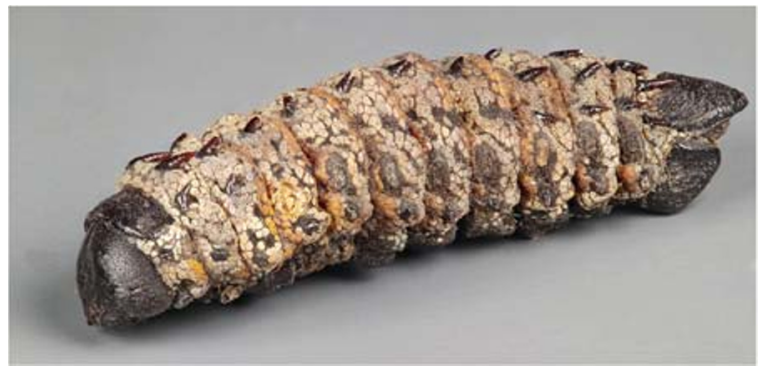

Photo 1 Dried mopane caterpillar Imbrasia belina (Lepidoptera: Saturnidae). Photo credits and copyright: Hans Smid-www.bugsinthepicture.com

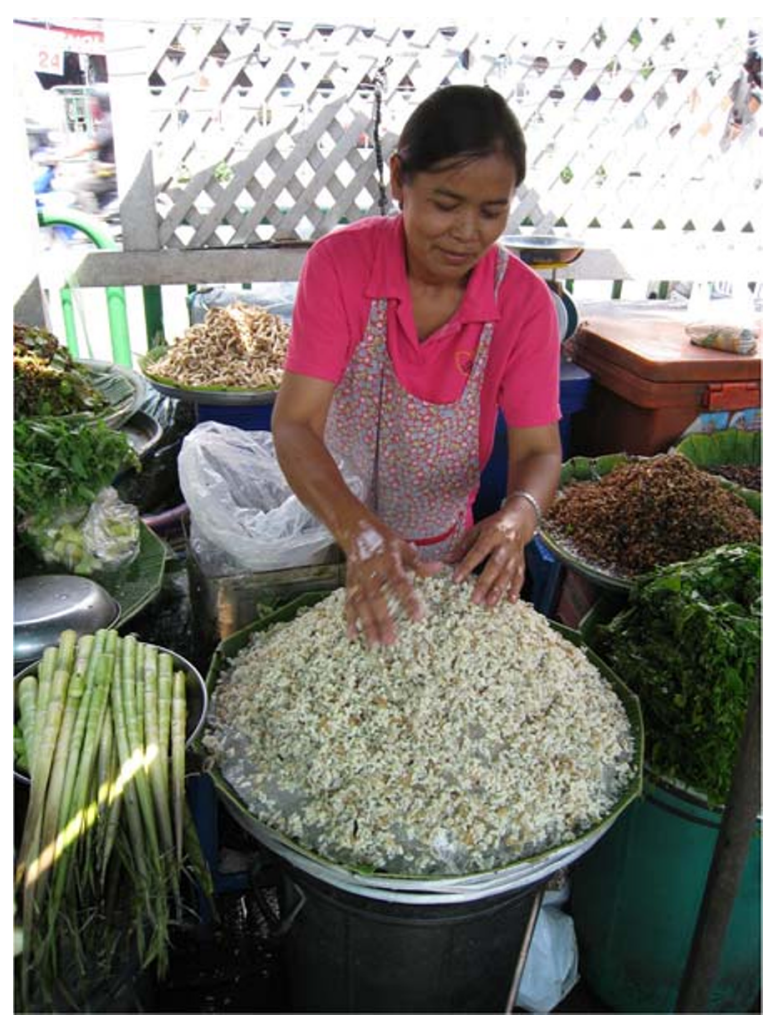

Photo 2 Pupae of the future queens of the ant, Oecophylla smaragdina (Hymenoptera: Formicidae) on a pile of ice at the Klong Toey market in Bangkok, Thailand. Photo by Arnold Van Huis

looking for meat alternatives, among which are cultured meat, plant-based meat alternatives, algae, mycoproteins, and insects (Van der Weele et al. 2019).

If we would like to promote insects as food and feed, harvesting from nature is no longer an option and we need to farm the insects. The number of insect species currently being reared for food and feed is limited. Those species that are used have already been reared as pet food for captive reptiles, fish, and birds, or as bait for fishing for some time. These insects can play a role as their production has been shown to have less environmental impact than livestock production (Van Huis and Oonincx 2017). Besides, several insect species can play a role in a circular economy as they are capable of biodegradation and biotransformation of organic side streams (Varelas 2019). In the last 10 years, the number of scientific publications on edible insects has increased exponentially (Van Huis 2020) and the number of startups is now estimated to be more than 290 worldwide (BugBurger 2020). Some companies have received millions of dollars to automate the production process. 


\section{Insect species as food and feed}

Insects are the yellow mealworms, the lesser mealworm, and the superworm (larvae of beetles from the family of Tenebrionidae); several cricket species, of which the most important one is the house cricket, Acheta domestica; and the migratory locust. As feed for animals, mealworms are used, but also the house fly and the black soldier fly (Hermetia illucens) (Photo 3). The last is becoming extremely popular and many companies are now engaged in its production, to a large degree, because it can be used to recycle many types of waste streams. Even straw, being fermented first by fungi, can be tackled by this insect (Gao et al. 2019). Spent mushroom substrate, which is available in very large quantities, could therefore be a suitable feed source for many insects (Cai et al. 2019). To bio-convert resources high fiber waste such as almond hulls by the black soldier fly, the carbon to nitrogen ratio has to be decreased and this can be done by nitrogen supplementation (Palma et al. 2019). It seems that up till now the insect species, manure being its natural habitat, has not shown to be affected by diseases.

There are insect species which can be semidomesticated such as palm weevil larvae (Van Itterbeeck and Van Huis 2012). Other insect species

a

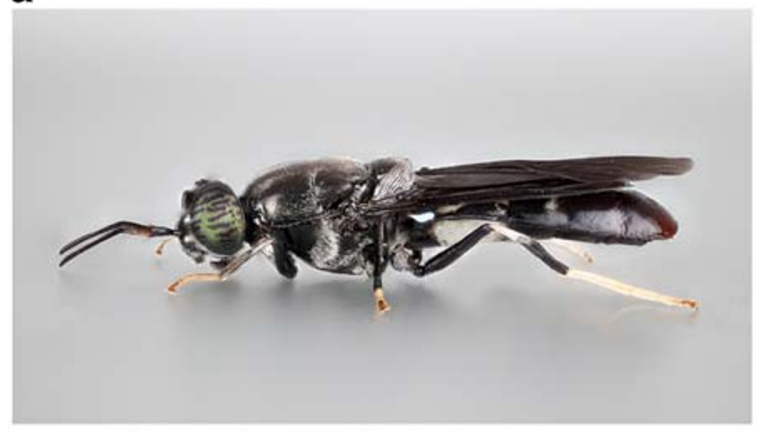

b

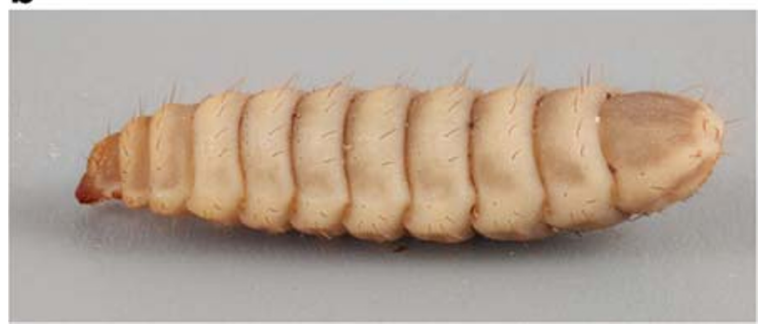

Photo 3 Adult (a) and prepupa (b) of the black soldier fly (Hermetia illucens) (Diptera: Stratiomyidae). Photo credits and copyright: Hans Smid-www.bugsinthepicture.com such as the edible grasshopper, Ruspolia differens, which is very popular in East Africa, are attempted to be reared on an artificial diet (Fombong et al. 2019). Probably, there are more species which need to be explored for mass rearing.

\section{Nutrition and health}

From reviewing 236 insect species, Rumpold and Schlüter (2013) concluded that many edible insects provide satisfactorily, with regard to energy and protein; meet amino acid requirements for humans; are high in monounsaturated fatty acids (MUFA) and/or polyunsaturated fatty acids (PUFA); and rich in several micronutrients, such as iron and zinc, as well as riboflavin, pantothenic acid, biotin, and in some cases folic acid. Payne et al. (2016), using nutritional models, concluded that several edible insect species compared similar to different meat types.

However, the nutritional value depends on the insect species and is influenced by numerous factors such as diet, stage harvested, and environmental factors (Finke and Oonincx 2014). The diet does not influence the protein content very much, but the fatty acid composition can be tailored to the target animals. For example, commercially produced insects are often low in n-3 fatty acids and have suboptimal $n-6 / n-3$ ratios. Oonincx et al. (2019) achieved optimal ratios by adding only 1$2 \%$ of flaxseed oil to the diet of house crickets, lesser mealworms, and black soldier flies. Oonincx et al. (2018) also showed that insects can synthesize vitamin $\mathrm{D}$ de novo and that the amounts depend on UVb irradiance and exposure duration.

Recent publications have shown that insects may improve human gut health. For example, Stull et al. (2018) showed that cricket powder supported growth of the probiotic bacterium, Bifidobacterium animalis. Also Mota de Carvalho et al. (2019) showed that powder of the yellow mealworm has a potential prebiotic effect. This prebiotic effect may be caused by the exoskeleton of insects, chitin (Komi et al. 2018), not only in humans (Stull et al. 2018) but also in fish (Rimoldi et al. 2019; Terova et al. 2019). Also insects have the largest repertoire of antimicrobial peptides, which has promoted their development as alternatives to conventional antibiotics, in an attempt to address 
the threat of multidrug-resistant pathogens (Tonk and Vilcinskas 2017). Water-soluble extracts of a number of insect species showed an antioxidant capacity (Messina et al. 2019) higher than fresh orange juice and olive oil (Di Mattia et al. 2019).

\section{Industrial production}

To produce insects, you need two units: a reproduction unit where adults can mate and lay their eggs and a production unit where the eggs are sown on a substrate. The larvae are then reared until the last larval stage. In the case of mealworms and black soldier larvae, trays are used. The substrate often is added during the rearing process. During this process, predators, parasitoids, and microorganisms may attack and infect the insects. Eilenberg et al. (2015) proposed several strategies to avoid these problems.

When the harvested stage is reached, e.g., last larval stages for mealworms and prepupae for the black soldier fly, the left-over substrate should be removed. Left over substrate can then be used as fertilizer, probably due chitin or its derivate chitosan, which triggers plant growth and induces plant defense (Sharif et al. 2018; Sharp 2013).

The larvae are then decontaminated and often, after mechanically removing the fat, dried. They can then be ground into insect meal. However, it is also possible to extract the fat, protein, and chitin. These can be used for several purposes. For example, oil can be used in feed, cosmetics (Verheyen et al. 2018), bio-lubricants (Alipour et al. 2019), or biodiesel (Wang et al. 2017). Proteins can be used in food and feed applications but also in technological applications such as bioplastics (Leni et al. 2017). Chitin and chitosan can be used in biomaterials and biomedical applications (Morganti et al. 2018).

A new area of research is that of breeding (genetically improving) the insect species. First of all there are several strains that can be used such as for black soldier fly (Zhou et al. 2013) and mealworms (Urs and Hopkins 1973). However, it is also possible to select for better performance, as was shown by 8 -years selection of yellow mealworms and larger pupal size, growth rate, fecundity, and efficiency of conversion of ingested food was found in the selected strain (Morales-Ramos et al.
2019). Compared with conventional production animals, the insects have a short life cycle, which is an advantage for breeding.

\section{Food safety and legislation}

When organic side streams are used, there is a risk of chemical and microbial contaminants. For example, antibiotic resistance genes and/or antibiotic-resistant microorganisms may be acquired by yellow mealworm larvae from the feed (Osimani et al. 2018). Concerning heavy metals, black soldier fly larvae can bioaccumulate cadmium and yellow mealworm larvae arsenic (Van der Fels-Klerx et al. 2016).

Bioaccumulation does not always occur and several edible insect species are able to degrade those contaminants. The black soldier fly has shown to be able to degrade pathogens (Erickson et al. 2004), mycotoxins (Purschke et al. 2017), insecticides (Purschke et al. 2017), and fungicides (Lalander et al. 2016). Also, the yellow mealworm, when wheat was contaminated with the mycotoxin deoxynivalenol, accumulated only very low levels of the mycotoxin, suggesting that it can still be used to produce a sustainable, safe protein source (Sanabria et al. 2019).

If patients are allergic to crustaceans or mites, is there a risk of cross-reactivity to different edible insects? This is likely, as it has been shown that insects and crustaceans, long considered widely separated branches of the arthropod family tree, actually belong together (Pennisi 2015). The risk of cross-reactivity is present, but appropriate food processing methods can reduce it (Pali-Schöll et al. 2019). However, on labels of the edible insect products marketed, there should be a warning on the label that allergenic risks exist.

IPIFF (2020) explains the legislation in the European Union. The classification of insects as novel food has been clarified through the adoption of Regulation EU No. 2015/2283, applicable on January 2018. Applicants are required to submit information to the European Commission; the European Food Safety Authority (EFSA) may be involved in the evaluation. Concerning insects as feed, manure and catering waste are not allowed as substrate to feed the insects. Insects can be fed to pets. Since the 1st of July 2017, the use of insect proteins originating from seven insect species is allowed 
in feed for aquaculture animals. However, insects are not yet allowed to be fed to poultry and pigs.

\section{Consumer attitudes}

Food neophobia (people refusing to taste and eat food items or foods they are not familiar with) plays a role in insect consumption. Only for about 10 years, insects have been brought on the food market. There are several strategies that are used to increase the acceptance of insect-based food products (Hartmann and Bearth 2019; Kauppi et al. 2019; Rumpold and Langen 2019; Van Huis 2017). One of them is to disguise the food in familiar products such as protein bars, burgers, bread, or pasta. Another is to provide information, not only on the sustainability of the insect product but also on the nutritional and health benefits and on food safety. Also, role models can play an important role, e.g., the endorsement of figures like Rene Redzepi, chef cook of Noma, a restaurant several times declared as the best in the world, and Kofi Annan, the late former secretary general of the United Nations (Van Huis et al. 2012). Also, the organization of bug banquets, in which the consumer can test insect products, is an important strategy, as the first time to taste an insect is always a challenge (Looy and Wood 2006). Children may also be targeted as they are not as biased yet (Geertsen 2019). Of course, the tastiness of the product is extremely important for new products, especially when the consumer is already reluctant to eat insects.

\section{Conclusions}

The attention to insects as food and feed is increasing exponentially on a global scale. This is prompted by the urge to find alternatives for meat, as the agricultural land area available will not be enough to respond to future demands. Also, there is concern about the negative environmental impact of the production of the common livestock species. Insects can be used both as food and feed, and several species are currently being farmed, and more and more in large-scale industrial facilities. The nutritional value of edible insects is similar to meat products and sometimes even better. There may also be nutritional benefits, as the exoskeleton of insects seems to function as a prebiotic. Besides, insects have the largest repertoire of antimicrobial peptides of all animal groups. Insect products are still too expensive, but this may be justified considering the health and environmental benefits. To lower the price, research is being conducted on automating production systems and on finding cheap substrates to feed the insects on. Several insect species can transform low-value organic side streams into high-value protein products. There is a tremendous interest in the black soldier fly because it can thrive on many organic side streams, including manure and catering waste. It can be used for biodegradation and when the larvae or prepupae are used for biotransformation. This fits well in the policy of a circular economy now adopted as a sustainable development strategy in many countries. More and more the combination with certain micro-organisms to facilitate this process is being investigated. Genetically improving insect strains is a new unexplored area, but promising considering the short life cycle of insects. The safety of insect products depends very much on the substrates on which insects are fed. There are several contaminants, such as pesticides and mycotoxins that can be degraded in the insect gut. However, others such as heavy metals may accumulate. Insects are new on the food market and because of neophobia consumers are reluctant to use them. However, there are a lot of strategies to convince consumers. The sector of edible insects is very new, but promising. Private entrepreneurs and academics are both engaged in developing insect products that are cheap, healthy, and safe, but cooperation with international and national governmental organizations is required to create an enabling environment.

Data availability Not applicable

Code availability Not applicable

Compliance with ethical standards

Conflict of interest The authors declare that they have no conflict of interest.

Ethics approval Not applicable

Consent to participate Not applicable 


\section{Consent for publication Not applicable}

Open Access This article is licensed under a Creative Commons Attribution 4.0 International License, which permits use, sharing, adaptation, distribution and reproduction in any medium or format, as long as you give appropriate credit to the original author(s) and the source, provide a link to the Creative Commons licence, and indicate if changes were made. The images or other third party material in this article are included in the article's Creative Commons licence, unless indicated otherwise in a credit line to the material. If material is not included in the article's Creative Commons licence and your intended use is not permitted by statutory regulation or exceeds the permitted use, you will need to obtain permission directly from the copyright holder. To view a copy of this licence, visit http://creativecommons.org/licenses/by/4.0/.

\section{References}

Alipour N, Vinnerås B, Gouanvé F, Espuche E, Hedenqvist MS (2019) A protein-based material from a new approach using whole defatted larvae, and its interaction with moisture. Polymers 11(287):1-14. https://doi.org/10.3390 /polym11020287

Bergier E (1941) Peuples entomophages et insectes comestibles: étude sur les moeurs de l'homme et de l'insecte. Imprimerie Rullière Frères, Avignon

Bodenheimer FS (1951). Insects as human food; a chapter of the ecology of man. Dr. W. Junk, Publishers, The Hague, 352 pp.

BugBurger (2020). The Eating insects startups: Here is the list of entopreneurs around the world! (http://www.bugburger. se/foretag/the-eating-insects-startups-here-is-the-list-ofentopreneurs-around-the-world/) (consulted the $3^{\text {rd }}$ of March 2020)

Cai M, Zhang K, Zhong W, Liu N, Wu X, Li W, Zheng L, Yu Z, Zhang J (2019) Bioconversion-composting of golden needle mushroom (Flammulina velutipes) root waste by black soldier fly (Hermetia illucens, Diptera: Stratiomyidae) larvae, to obtain added-value biomass and fertilizer. Waste Biomass Valor 10:265-273. https://doi.org/10.1007/s12649-0170063-2

DeFoliart GR (1999) Insects as food: why the western attitude is important. Annu Rev Entomol 44:21-50

DeFoliart GR (2002). The human use of insects as food resource: a bibliographic account in progress. Department of Entomology, University of Wisconsin-Madison Availabe online at: http://www.food-insects.com/book7_31/The\%20 Human $\% 20$ Use $\% 20$ of $\% 20$ Insects $\% 20$ as $\% 20$ a $\% 20$ Food\%20Resource.htm

Di Mattia C, Battista N, Sacchetti G, Serafini M (2019) Antioxidant activities in vitro of water and liposoluble extracts obtained by different species of edible insects. Front Nutr 6. https://doi.org/10.3389/fnut.2019.00106

Eilenberg J, Vlak JM, Nielsen-LeRoux C, Cappellozza S, Jensen AB (2015) Diseases in insects produced for food and feed. J
Insects Food Feed 1:87-102. https://doi.org/10.3920 /JIFF2014.0022

Erickson MC, Islam M, Sheppard C, Liao J, Doyle MP (2004) Reduction of Escherichia coli 0157:H7 and Salmonella enterica serovar Enteritidis in chicken manure by larvae of the black soldier fly. J Food Prot 67:685-690

Finke MD and Oonincx D (2014). Chapter 17 - Insects as food for insectivores. In: M.G.R. Juan Morales-Ramos, David Shapiro-Ilan. (Ed.), Mass production of beneficial organisms. Academic Press, San Diego, pp. 583-616

Fombong F, Kinyuru J, Tanga CM, Van Der Borght M and Vanden Broeck J (2019). Effect of light regime on fitness parameters of farmed Ruspolia differens fed on articial diet. Book of abstracts Insecta 2019 conference, 5-6 September, Potsdam: 83

Gao Z, Wang W, Lu X, Zhu F, Liu W, Wang XP, Lei C (2019) Bioconversion performance and life table of black soldier fly (Hermetia illucens) on fermented maize straw. J Clean Prod 230:974-980. https://doi.org/10.1016/j.jclepro.2019.05.074

Geertsen A (2019). Are edible insects the new black? An exploratory study assessing Danish children's perception of edible insects. Master thesis series in environmental studies and sustainability science, no 2019:002. Lund University

Hartmann C, Bearth A (2019) Bugs on the menu: drivers and barriers of consumer acceptance of insects as food. In: Sogari G, Mora C, Menozzi D (eds) Edible insects in the food sector: methods. Current Applications and Perspectives. Springer International Publishing, Cham, pp 45-55

IPIFF (2020) EU legislation. International Platform of Insects for Food and Feed (IPIFF), Brussels. http://ipiff.org/insects-eulegislation/. Accessed 19 March 2020

Jongema Y (2017) List of edible insect species of the world. Laboratory of Entomology, Wageningen University, The Netherlands. http://www.ent.wur. $\mathrm{nl} / \mathrm{UK} /$ Edible+insects/Worldwide+species+list/. Accessed 16 Apr 2020

Kauppi S-M, Pettersen I, Boks C (2019) Consumer acceptance of edible insects and design interventions as adoption strategy. Intern J Food Design 4:39-62. https://doi.org/10.1386 /ijfd.4.1.39_1

Komi DEA, Sharma L, Dela Cruz CS (2018) Chitin and its effects on inflammatory and immune responses. Clin Rev Allergy Immunol 54:213-223. https://doi.org/10.1007/s12016-0178600-0

Lalander C, Senecal J, Gros Calvo M, Ahrens L, Josefsson S, Wiberg K, Vinnerås B (2016) Fate of pharmaceuticals and pesticides in fly larvae composting. Sci Total Environ 565: 279-286. https://doi.org/10.1016/j.scitotenv.2016.04.147

Leni G, Caligiani A, Marseglia A, Baldassarre S, Maistrello L and Sforza S (2017). Fractionation of black soldier fly biomolecules for feed/food or technological applications. Poster valoribio. University of Parma. https://www.researchgate. net/publication/323144366

Lesnik JJ (2017) Not just a fallback food: global patterns of insect consumption related to geography, not agriculture. American J Hum Biol 29:e22976. https://doi.org/10.1002/ajhb.22976

Looy H, Wood JR (2006) Attitudes toward invertebrates: are educational "bug banquets" effective? J Environ Educ 37: 37-48. https://doi.org/10.3200/JOEE.37.2.37-48

McGrew WC (2014) The 'other faunivory' revisited: insectivory in human and non-human primates and the evolution of 
human diet. J Hum Evol 71:4-11. https://doi.org/10.1016/j. jhevol.2013.07.016

Messina CM, Gaglio R, Morghese M, Tolone M, Arena R, Moschetti G, Santulli A, Francesca N, Settanni L (2019) Microbiological profile and bioactive properties of insect powders used in food and feed formulations. Foods (Basel, Switzerland) 8:-400. https://doi.org/10.3390/foods8090400

Morales-Ramos JA, Kelstrup HC, Rojas MG and Emery V (2019). Body mass increase induced by eight years of artificial selection in the yellow mealworm (Coleoptera: Tenebrionidae) and life history trade-offs. J Insect Sci 19. https://doi. org/10.1093/jisesa/iey110

Morganti P, Danti S, Coltelli MB (2018) Chitin and lignin to produce biocompatible tissues. Res Clin Dermatol 1:5-11

Mota de Carvalho N, Teixeira F, Silva S, Raquel Madureira A and Pintado M (2019). Potential prebiotic activity of Tenebrio molitor insect flour using an optimized in vitro gut microbiota model Food \& Function 10. https://doi.org/10.1039/C8 FO01536H

Oonincx DGAB, Van Keulen P, Finke MD, Baines FM, Vermeulen M, Bosch G (2018) Evidence of vitamin D synthesis in insects exposed to UVb light. Sci Rep 8:1080710810. https://doi.org/10.1038/s41598-018-29232-w

Oonincx DGAB, Laurent S, Veenenbos ME, Van Loon JJA (2019) Dietary enrichment of edible insects with omega 3 fatty acids. Insect Sci. https://doi.org/10.1111/1744-7917.12669

Osimani A, Milanovic V, Cardinali F, Garofalo C, Clementi F, Ruschioni S, Riolo P, Isidoro N, Loreto N, Galarini R, Moretti S, Petruzzelli A, Micci E (2018) Distribution of transferable antibiotic resistance genes in laboratory-reared edible mealworms (Tenebrio molitor L.). Front Microbiol 9: 2702. https://doi.org/10.3389/fmicb.2018.02702

Pali-Schöll I, Meinlschmidt P, Larenas-Linnemann D, Purschke B, Hofstetter G, Rodríguez-Monroy FA, Einhorn L, MothesLuksch N, Jensen-Jarolim E, Jäger H (2019) Edible insects: cross-recognition of $\mathrm{IgE}$ from crustacean- and house dust mite allergic patients, and reduction of allergenicity by food processing. WAO J 12:45-54. https://doi.org/10.1016/j. waojou.2018.10.001

Palma L, Fernandez-Bayo J, Niemeier D, Pitesky M, VanderGheynst JS (2019) Managing high fiber food waste for the cultivation of black soldier fly larvae. Sci Food 3:15. https://doi.org/10.1038/s41538-019-0047-7

Payne CLR, Scarborough P, Rayner M, Nonaka K (2016) Are edible insects more or less 'healthy' than commonly consumed meats? A comparison using two nutrient profiling models developed to combat over- and undernutrition. Eur J Clin Nutr 70:285-291. https://doi.org/10.1038 /ejcn.2015.149

Pennisi E (2015) All in the (bigger) family: revised arthropod tree marries crustacean and insect fields. Sci Total Environ 347: 220-221. https://doi.org/10.1126/science.347.6219.220

Purschke B, Scheibelberger R, Axmann S, Adler A, Jäger H (2017) Impact of substrate contamination with mycotoxins, heavy metals and pesticides on the growth performance and composition of black soldier fly larvae (Hermetia illucens) for use in the feed and food value chain. Food Addit Contam 34:1410-1420. https://doi.org/10.1080 /19440049.2017.1299946

Rimoldi S, Gini E, Iannini F, Gasco L, Terova G (2019) The effects of dietary insect meal from hermetia illucens prepupae on autochthonous gut microbiota of rainbow trout (Oncorhynchus mykiss). Animals 9:143. https://doi. org/10.3390/ani9040143

Rumpold BA, Langen N (2019) Potential of enhancing consumer acceptance of edible insects via information. J Insects Food Feed 5:45-53. https://doi.org/10.3920/JIFF2018.0041

Rumpold BA, Schlüter OK (2013) Nutritional composition and safety aspects of edible insects. Mol Nutr Food Res 57:802823. https://doi.org/10.1002/mnfr.201200735

Sanabria CO, Hogan N, Madder K, Gillott C, Blakley B, Reaney M, Beattie A, Buchanan F (2019) Yellow mealworm larvae (Tenebrio molitor) fed mycotoxin-contaminated wheat - a possible safe, sustainable protein source for animal feed? Toxins 11:282. https://doi.org/10.3390/toxins 11050282

Sharif R, Mujtaba M, Ur Rahman M, Shalmani A, Ahmad H, Anwar T, Tianchan D, Wang X (2018) The multifunctional role of chitosan in horticultural crops; a review. Molecules 23. https://doi.org/10.3390/molecules23040872

Sharp RG (2013) A review of the applications of chitin and its derivatives in agriculture to modify plant-microbial interactions and improve crop yields. Agron. 3:757-793. https://doi. org/10.3390/agronomy3040757

Springmann M, Clark M, Mason-D’Croz D, Wiebe K, Bodirsky BL, Lassaletta L, de Vries W, Vermeulen SJ, Herrero M, Carlson KM, Jonell M, Troell M, DeClerck F, Gordon LJ, Zurayk R, Scarborough P, Rayner M, Loken B, Fanzo J, Godfray HCJ, Tilman D, Rockström J, Willett W (2018) Options for keeping the food system within environmental limits. Nature 562:519-525. https://doi.org/10.1038/s41586018-0594-0

Stull VJ, Finer E, Bergmans RS, Febvre HP, Longhurst C, Manter DK, Patz JA, Weir TL (2018) Impact of edible cricket consumption on gut microbiota in healthy adults, a double-blind, randomized crossover trial. Sci Rep 8:10762. https://doi. org/10.1038/s41598-018-29032-2

Terova G, Rimoldi S, Ascione C, Gini E, Ceccotti C, Gasco L (2019) Rainbow trout (Oncorhynchus mykiss) gut microbiota is modulated by insect meal from Hermetia illucens prepupae in the diet. Rev Fish Biol Fish 29:465-486. https://doi. org/10.1007/s11160-019-09558-y

Tonk M, Vilcinskas A (2017) The medical potential of antimicrobial peptides from insects. Curr Top Med Chem 17:554-575

Urs KCD and Hopkins TL (1973). Effect of moisture on the lipid content and composition of two strains of Tenebrio molitor $\mathrm{L}$. (Coleoptera, Tenebrionidae). J. Stored Prod. Res. 8: 299-305

Van der Fels-Klerx HJ, Camenzuli L, Van der Lee MK, Oonincx DGAB (2016) Uptake of cadmium, lead and arsenic by Tenebrio molitor and Hermetia illucens from contaminated substrates. PLoS One 11:e0166186. https://doi.org/10.1111 /1541-4337.12385

Van der Weele C, Feindt P, Van der Goot JA, Van Mierlo B, Van Boekel M (2019) Meat alternatives; an integrative comparison. Trends Food Sci Technol 88:505-512. https://doi. org/10.1016/j.tifs.2019.04.018

Van Huis A (2017) Edible insects: marketing the impossible? J Insects Food Feed 3:67-68. https://doi.org/10.3920 /JIFF2017.x003

Van Huis A (2018) Chapter 11. Insects as human food. In: Ethnozoology: animals in our lives (Eds.: Alves Rômulo Ulysses Paulino de Albuquerque). Elsevier, Amsterdam, pp $195-213$ 
Van Huis A (2020) Insects as food and feed, a new emerging agricultural sector: a review. J Insects Food Feed 6:27-44. https://doi.org/10.3920/JIFF2019.0017

Van Huis A, Oonincx DGAB (2017) The environmental sustainability of insects as food and feed. A review. Agron Sustain Dev 37:43. https://doi.org/10.1007/s13593-017-0452-8

Van Huis A, Van Gurp H, Dicke M (2012) Het insectenkookboek (The insect cookbook). Atlas, Amsterdam, $190 \mathrm{pp}$

Van Huis A, Itterbeeck JV, Klunder H, Mertens E, Halloran A, Muir G and Vantomme P (2013). Edible insects: future prospects for food and feed security. FAO Forestry Paper 171. Rome, Food and Agriculture Organization of the United Nations, Rome and Wageningen University and Research Centre, the Netherlands. 187 pp.

Van Itterbeeck J, Van Huis A (2012) Environmental manipulation for edible insect procurement: a historical perspective. J Ethnobiol Ethnomed 8:1-19. https://doi.org/10.1186/17464269-8-3

Varelas V (2019) Food wastes as a potential new source for edible insect mass production for food and feed: a review.
Fermentation 5:81. https://doi.org/10.3390 /fermentation5030081

Verheyen GR, Ooms T, Vogels L, Vreysen S, Bovy A, Van Miert S, Meersman F (2018) Insects as an alternative source for the production of fats for cosmetics. J Cosmet Sci 69:187-202

Wang H, Rehman KU, Liu X, Ziniu Y (2017) Insect biorefinery: a green approach for conversion of crop residues into biodiesel and protein. Biotech Biofuels 10

Zhou F, Tomberlin JK, Zheng L, Yu Z, Zhang J (2013) Developmental and waste reduction plasticity of three black soldier fly strains (Diptera: Stratiomyidae) raised on different livestock manures. J Med Entomol 50:1224-1230. https://doi.org/10.1603/ME13021

Publisher's note Springer Nature remains neutral with regard to jurisdictional claims in published maps and institutional affiliations. 